Професорката по македонска книжевност на МГУ «М.В. Ломоносов», Ала Шешкен - добитничка на Почесното Рациново признание за 2021 година

I. Antonovski (Skopje, Republic of Macedonia)

\title{
Awarding of the Ratsin Honorary Prize for 2021 to Professor of Lomonosov Moscow State University A.G. Sheshken
}

Кога се пишува текст посветен на актуелен настан од културната стварност, неретко, причината да се напише текстот е многу поважна од поводот. Не само затоа што таа е душата на напишаното (вклучително и она што е напишано меѓу редовите), туку и затоа што на неа се темели и самата потреба да се напише (уште еден) текст за конкретниот настан. Затоа што таа, всушност и ги надминува димензиите на поводот и на настанот-форма му дава суштина, а нема да се згреши ако се напомене дека му дава и смисла. Така е и во овој случај. Поводот за овој текст е годинешното, 58. издание на меѓународната културна манифестација «Рацинови средби» - една од двете книжевни манифестации коишто имаат најдолга и најбогата традиција во современата македонска држава. Но причината да се случи овој текст е тоа што годинешна добитничка на Почесното Рациново признание е руската славистика и македонистика, редовната професорка на Московскиот државен универзитет «М.В. Ломоносов», академик Ала Генадјевна Шешкен. Впрочем, во овој случај, «Рациновите средби» се настан во формална смисла - настан што од првата половина на седмата деценија на минатиот век, во различни организациски облици се случува секоја година, но настан во суштинска смисла е токму тоа што Шешкен се вброи меѓу добитниците на ова признание коешто се доделува за остварувања со коишто се промовираат и афирмираат македонскиот јазик, книжевност и култура. Настан за којшто без ни малку хиперболизација или глорификација би можело да се каже дека се случува само еднаш во деценијата (а можеби и во подолг период), не само во рамките на оваа манифестација, туку и воопшто во современото македонско културно живеење - со вакво признание да се валоризира делото на современ странски славист и македонист со исклучително голем влог за македонската книжевна наука, а којшто е од форматот на Шешкен.

Несомнено, Почесното Рациново признание е најпрестижното одликување коешто се доделува за промовирање и афирмирање на македонскиот јазик, книжевност и култура, ноостварувањата на Шешкен го надминуваат сето она што ја сочинува семантичката полност на термините «афирмација» и «промоција». Нејзини- 
от досегашен научноистражувачки опус не е само евалуација и синтетизирање на есенцијалните согледби, ставови и становишта на македонската книжевна наука за македонската книжевност во XX век и/или само нивно приопштување и претставување пред руската јавност, туку и влог преку којшто тие се и надградени, односно надополнети. Накусо, станува збор за опус во којшто се вбројуваат трудови коишто овозможуваат поинакво, автентично читање на голем дел од македонскиот поетски, прозен и драмски корпус на минатото столетие, коишто се референци без коишто денес не би можел да се подготви ниту еден студиозен и сеопфатен преглед или приказ на македонската современа книжевност на XX век. Накусо, во трудовите на Шешкен не е само прераскажано она што е претходно запишано од македонските книжевни историчари и критичари (иако е и повеќе од забележливо дека Шешкен е темелито и целосно запознаена со сите клучни референци на македонските книжевни историчари и критичари), туку се претставени и нови, исклучителни, критички и аналитички ставови и согледби коишто овозможуваат и нови перспективи во исчитувањето на македонското лепословие.

Само за илустрација би посочиле дека денес, веќе не може да се пишува монографски труд којшто би претставувал историја на македонскиот книжевен XX век, а како клучна референца да се нема предвид докторската дисертација на Шешкен, на тема «Македонската книжевност на XX век: формирањето и развојот», одбранета на Московскиот државен универзитет «М.В. Ломоносов» во 2008 година. Не само затоа што е прва докторска дисертација посветена на македонската книжевност, а одбранета во Русија, туку затоа што е единствениот авторски потфат во славистиката, од понов датум, којшто цели и успева да ја валоризира и да ја претстави големата слика на оваа епоха на македонската пишана реч, од соодветна временска дистанца. Потфатот на Шешкен следи 18 години по објавувањето на првата историја на македонскиот книжевен XX век од Миодраг Друговац, но во себе содржи не само фактографија и синтентизирање на дотогашните референтни осврнувања кон македонската книжевност од XX век, туку исклучително автентични, научноистражувачки и критички анализи, од коишто еден дел се и компративни и го имаат предвид клучниот културен и севкупен јужнословенски контекст, но неретко овозможуваат и компаративни согледувања со остварувањата на руската книжевност - анализи коишто отвораат нови поглавја во проучувањето и анализирањето на естетските достигнувања на македонскиот автор од минатото столетие. Впрочем, оваа докторска дисертација, подоцна објавена и како монографска публикација е и најобемната сеопфатна студија за современата македонска книжевност којашто во изминатите две децении ја има подготвено / напишано некој странски македонист и славист.

Но посветеноста на Шешкен не запира со книжевниот век којшто веќе е зад нас, туку продолжува и со интерес и анализа и на најновите развојни етапи на современата македонска книжевност и со постојано критичко следење на тековната, македонска книжевна продукција, и од позиција на книжевен научник, и од позиција на преведувач. Несомнено, и надвор од македонскиот културен контекст, денес, таа се издвојува меѓу ретките постојано посветени проучувачи на странска, нематична современа книжевност.

Истовремено, не може да не се нагласи и нејзиниот влог за афирмирањето на македонскиот јазик, книжевност и култура и преку својата дејност како профеcop / предавач. Сигурни сме дека ако од временска дистанца се направи анализа ќе се потврди дека остварувањата со студентите по македонистика на Шешкен ќе 
се издвојат како најзначајните не само за актуелната афирмација на македонската книжевност во една голема европска култура (впрочем, треба да се има предвид и големиот број книжевни преводи од македонски на руски јазик, остварени во изминатите две децении), туку и за натамошното не само афирмирање, туку и проучување на поновата македонска книжевност во поширок европски контекст.

Ретки се националните книжевности и култури коишто на современ план имаат толку темелити странски познавачи и проучувачи. Но, уште поретки се научниците и истражувачите коишто имаат остварено толку оригинални научноистражувачки трудови преку коишто се доаѓа до клучни, нови согледби, интерпретации и оцени за една национална книжевност, колку што Шешкен досега има остварено со нејзиното пасионирано проучување на македонската книжевна историја и на актуелната македонска книжевна стварност. Без ни малку хиперболизирање може да се каже дека влогот на Шешкен во проучувањето и афирмирањето на македонската современа книжевност, на современ план е еквивалент на влогот на Рина Усикова во проучувањето и афирмирањето на македонскиот јазик во XX век. Оттука, не може да не се напомене дека беше логично и очекувано, Почесното Рациново признание да ѝ биде доделено и многу порано. Но, сепак, се случи во вистински момент, во година којашто е исклучително важна за современата македонска култура - годината во којашто се одбележуваат 100 години од раѓањето на најмаркантната, централна личност на македонскиот XX век, основоположникот на македонистиката, академикот Блаже Конески. Во ваква година, добитник на Почесното Рациново признание, очекувано и нужно беше на биде достоинствен следбеник на Конески од редот на странските македонисти. Убедени сме - подобар избор од Шешкен, оваа година, не можеше да има.

Меѓу меѓниците на секоја современа национална култура се издвојуваат по неколку културни манифестациисо традиција, коишто не само што ги претставуваат достоинствата и остварувањата на конкретната култура, туку и ги воспоставуваат синтезите меѓу неа и другите култури. Манифестации-меѓници коишто се важни за естетската, а неретко и за научната вертикала на националната култура, но едновремено се важни и затоа што од нив произлегуваат идеи и подвизи (творечки, книжевно-платформски и организациски) коишто придонесуваат за натамошните текови во современото културно живеење. Таквите манифестации претставуваат / постануваат синоними за конкретната национална култура.

«Рациновите средби», како една од двете најстари книжевни манифестации од меѓународен карактер во современата македонска култура се манифестација-меѓник којашто има такво значење на македонското културно живеење - манифестација којашто се одликува со исклучителна комплексност и книжевна сеопфатност, достојна на сестраноста на основоположникот на современата македонска книжевност, Коста Солев Рацин, во чијашто чест досега се одржаа веќе 58. пати. Поконкретно, Рацин не беше само поет и мислител, ами и прозаист, есеист, книжевен и општествен критичар, преведувач, публицист... Во обем и формат којшто го надминува вообичаениот книжевен дофат на поединецот во конкретното доба на македонската култура, во специфичните околности во четвртатата и петтата деценија на минатиот век. Неслучајно, Конески ја споредуваше творечката личност на Рацина со онаа на Мајаковски. Оттука, не изненадува што «Рациновите средби» не се само поетска манифестација и покрај поетските читања и дебати, 
туку уште од самите почетоци, нивна програмска содржина се и научните симпозиуми, по што започнува да се доделува и Рациновото признание за прозно дело од македонски автор, со коешто, ако погледнеме наназад, се имаат закитено дел од најзначајните македонски прозни остварувања, и тоа дел од нив во вистинско време, кога биле дел од литературата на авангардата. Всушност, ако критички се анализираат македонските книжевни награди, токму Рациновото признание се издвојува како престижно признание за прозно дело коешто ја опфаќа севкупната актуелна македонска продукција (во споредба со наградата «Стале Попов» за којашто може да конкурираат само членовите на Друштвото на писателите на Македонија и наградата Роман на годината, којашто од севкупното прозно творештво е посветена само на еден прозен жанр - романот). И не само тоа, туку како такво признание, има и најдолга традиција. Оттука, Почесното Рациново признание можеби е последното, но е клучно камче коешто е ставено во мозаикот на оваа манифестација, којашто од нејзиното прво одржување наваму, од југословенска, а потоа балканска, прерасна во меѓународна манифестација којашто обединува книжевници од сите меридијани и неслучајно, во книжевниот свет е еден од синонимите за современата македонска култура.

Затоа, неизбежно е да се напомене дека доделувањето на признанието од манифестација од овој формат е и настан во биографијата на Ала Шешкен, во делот на валоризацијата на нејзиниот научноистражувачки влог во македонистиката и особено во македонската книжевна наука. На Почесното Рациново признание му претходеа и други признанија и валоризации за/на научноистражувачките потфати на Шешкен меѓу коишто секако се издвојува приемот во Македонската академија на науките и уметностите (МАНУ), во 2006 година, како член надвор од работниот состав, но и меѓународно признание «Блаже Конески», коешто МАНУ ѝ го додели за посебен придонес во проучувањето и афирмација на македонската книжевност и на македонскиот јазик, во 2015 година. Сепак, едновремено, сите овие признанија би требало да се перципираат и како логична последователност и долг на националната култура кон еден исклучителен зналец со целоживотна посветеност на проучување и исчитување на нејзината национална книжевност. Ала Шешкен е токму таков, исклучителен зналец со целоживотна посветеност на проучување и исчитување на македонската книжевност.

Сепак, кога се говори за научноистражувачкиот влог на академик Шешкен во македонистиката, како и за влогот во нејзината афирмација, дури и кога тоа, како во случајов, е поводно, по доделувањето на Почесното Рациново признание, не може, а да не се напоменат уште неколку факти од биографијата на истакнатата руска македонистка и славистка.

Таа е исклучителен познавач не само на македонската, туку и на другите јужнословенски книжевности, но неспорно, најголем е влогот што го има дадено за проучување и афирмација на македонската книжевност. Потврда на тоа е фактот што иако, хронолошки, најпрво нејзиниот интерес е насочен кон српската книжевност, најголемиот дел од нејзините повеќе од 200 научни трудови објавени во Русија и во странство, се од областа на македонистиката или пак, ако се од сферата на славистиката во пошироки рамки, речиси секогаш го опфаќаат и македонскиот книжевен контекст. Меѓу научните трудови на Шешкен се вбројуваат и пет монографски публикации, а од нив дури три се посветени исклучиво на 
македонската книжевност. Едновремено, мора да се подвлече дека и во првата монографска публикација на Шешкен, којашто компаративно ги анализира руската книжевност и книжевностите од некогашниот југословенски книжевен и културен ареал, одделно внимание е посветено на македонската книжевност, што е само уште една од многуте потврди за нејзиниот влог во етаблирањето на научната мисла за македонската книжевност во современиот славистички свет. Но уште поголема потврда е нејзиното учество о фундаменталните трудови на Институтот по славјановедение при Руската академија на науките (РАН) - сите трудови потпишани (и) со нејзиното име се посветени на различни развојни етапи на современата македонска книжевност.

Не може, а да не се напомене и дека Шешкен, веќе години наназад, не само што е редовна учесничка на летната школа (а од оваа година кога се одржа за првпат и зимската школа) на Меѓународниот семинар за македонски јазик, литература и култура при Универзитетот «Св. Кирил и Методиј» во Скопје (МСМЈЛК), туку се вбројува и меѓу семинаристите - странски македонисти, коишто како резултат на своето учество имаат остварено најголеми натамошни научноистражувачки, но и преведувачки потфати со македонската книжевност. Ова може да се согледа и доколку се анализираат зборниците од Меѓународната научната конференција во рамките на МСМЈЛК од последните две децении - речиси нема зборник во којшто нема научен труд на Шешкен. А сите трудови отвораат или одговараат значајни и големи прашања за македонската книжевна стварност, со коишто Шешкен, и на самите конференции, редовно поттикнува разговори, дебати и размисли меѓу славистите и македонистите.

Но исто толку важно е и што на школите на МСМЈЛК, покрај Шешкен, редовни учесниците се и нејзините студентки и студенти по македонистика, коишто години наназад се вбројуваат меѓу најактивните семинаристи, а по посетата на школата на МСМЈЛК остваруваат и позначајни потфати посветени на македонистиката - значајни научни трудови, преводи, магистерски трудови итн. Сите тие се потврда дека Шешкен не само што е голема посветеничка на македонската култура и книжевност, туку љубовта кон македонистиката, катадневно ја пренесува и на своите студенти - на своите наследници, коишто придонесуваат мостот меѓу двете култури и двата народна не само да опстојува, туку и постојано да се зацврстува, на современ план. За да се успее во тоа, не е потребно да се биде само исклучителен научник и истражувач, туку и одличен предавач, извонреден пренесувач на знаење, едукатор во вистинска смисла на зборот... Само така и може да се пренесе и создаде љубов кон одредена област за таа и на следните генерации да им постане животен професионален предизвик. Ала Шешкен успева кај своите студенти - наследници да им ја пренесе и кај нив да ја поттикне љубовта кон македонското лепословие.

Сето ова, во различни форми, веќе и беше кажано на годинешното издание на «Рациновите средби». Но, за жал, поради пандемијата на ковид-19, Шешкен не беше во можност физички да присуствува и учествува на манифестацијата. Ама нејзината видеобелешка - поздравно обраќње, којашто не беше клишеизиран говор, ами беседа за современата македонска книжевност и дел од нејзините достоинства - творештвата на Рацин и Конески, уште еднаш потврди дека сето ова е голема вистина за една голема македонистка од Русија. 
За крај, наместо некаков заклучок, нужна е една напомена. Почесното Рациново признание не е и не смее да се перципира како награда за Шешкен за остварен научноистражувачки максимум во областа на македонистиката или како награда за животно дело. Научноистражвачка инвентивност на Шешкен при читањето на страниците македонската современа книжност, како и нејзината постојана посветеност на следењето и анализирањето на најновата македонска книжевна продукција, укажуваат дека таа има уште многу што да каже и напише за македонското лепословие - уште многу научноистражувачки потфати и резултати потпишани од неа, како еден од столбовите и на македонската книжевна наука. Се надеваме дека сето тоа ќе се оствари, а дека признанијата за остварен научноистражувачки максимум во областа на македонистиката и за животно дело, допрва ќе следуваат во децениите што се пред нас.

Годинава, во текот на активностите со коишто се одбележува стогодишнината од раѓањето на Конески, неретко се сеќаваме на зборовите на истакнатиот македонски писател, кому Шешкен му посвети неколку научни трудови - Петре М. Андреевски: «Дај Боже, барем на секои сто години да ни се раѓа по еден Блаже Конески». Во оваа пригода, не може а да не се рече: Дај Боже, барем на секои десет години да се раѓa по еден странски македонист од форматот на Ала Шешкен. И дај Боже, на секој значаен европски и светски универзитетски центар, како што е «М.В. Ломоносов», секогаш да има по еден познавач и истражувач на македонската книжевност од форматот на Ала Шешкен.

Сведения об авторе:

Иван Антоновски, магистер по филолошки науки независимый исследователь
Ivan Antonovski, M.Sc. in Philology Independent Researcher i.antonovski@gmail.com 